Article

\title{
Synthesis of Household Yard Area Dynamics in the City of San Juan Using Multi-Scalar Social-Ecological Perspectives
}

\author{
Elvia J. Meléndez-Ackerman ${ }^{1, *}$, Christopher J. Nytch ${ }^{1}$, Luis E. Santiago-Acevedo ${ }^{2}$, \\ Julio C. Verdejo-Ortiz ${ }^{2}$, Raúl Santiago-Bartolomei ${ }^{3}$, Luis E. Ramos-Santiago ${ }^{4}$ and \\ Tischa A. Muñoz-Erickson ${ }^{5}$ \\ 1 Department of Environmental Sciences, University of Puerto Rico, \\ Río Piedras Campus PO Box 70377 San Juan, Puerto Rico 00931-8377, USA; chris.nytch@ites.upr.edu \\ 2 Graduate School of Planning, University of Puerto Rico, Río Piedras Campus, PO Box 23354, San Juan, \\ Puerto Rico 00931-3354, USA; santiago.luis47@gmail.com (L.E.S.-A.); juliocv@gmail.com (J.C.V.-O.) \\ 3 Sol Price School of Public Policy, University of Southern California, Lewis Hall 312, Los Angeles, \\ CA 90089-0626, USA; raulsant@usc.edu \\ 4 Department of Urban and Regional Planning, Florida State University, 330 Bellamy Bldg., \\ 113 Collegiate Loop, PO Box 3062280, Tallahassee, FL 32306, USA; estudiopd@gmail.com \\ 5 International Institute of Tropical Forestry, US Forest Service, Jardín Boánico Sur, 1201 Calle Ceiba, \\ Río Piedras, Puerto Rico 00926-1119, USA; tamunozerickson@fs.fed.us \\ * Correspondence: elmelend@gmail.com; Tel.: +1-787-764-0000 (ext. 88197)
}

Academic Editor: William D. Shuster

Received: 20 January 2016; Accepted: 28 April 2016; Published: 18 May 2016

\begin{abstract}
Urban sustainability discourse promotes the increased use of green infrastructure (GI) because of its contribution of important ecosystem services to city dwellers. Under this vision, all urban green spaces, including those at the household scale, are valued for their potential contributions to a city's social-ecological functioning and associated benefits for human well-being. Understanding how urban residential green spaces have evolved can help improve sustainable urban planning and design, but it requires examining urban processes occurring at multiple scales. The interaction between social structures and ecological structures within the subtropical city of San Juan, the capital and the largest city of Puerto Rico, has been an important focus of study of the San Juan ULTRA (Urban Long-Term Research Area) network, advancing understanding of the city's vulnerabilities and potential adaptive capacity. Here we provide a synthesis of several social-ecological processes driving residential yard dynamics in the city of San Juan, Puerto Rico, through the evaluation of empirical findings related to yard management decisions, yard area, and yard services. We emphasize the role of factors occurring at the household scale. Results are discussed within the context of shrinking cities using an integrated, multi-scalar, social-ecological systems framework, and consider the implications of household green infrastructure for advancing urban sustainability theory.
\end{abstract}

Keywords: household yards; social ecological systems; green infrastructure (GI); sustainability; shrinking cities; ecosystem services

\section{Introduction}

\subsection{Background}

The development of sound strategies for the management of green infrastructure (GI) in cities is increasingly linked to current visions of urban adaptive capacity and resilience planning $[1,2]$. Green spaces, whether urban or rural, offer humans a variety of ecological services that ultimately contribute to human well-being and security [3-5], typically at localized scales directly experienced by 
individuals. Within cities, residential landscapes are often a dominant land use [6-8]. From an urban sustainability and adaptive capacity perspective, domestic yards, when managed appropriately, could provide residents with mitigation against island heat, storm-attenuation services, cultural services like place-making and nature fulfillment, and even health benefits such as the production of food and medicinal plants, among other things $[9,10]$. Understanding what factors may lead to changes in these spaces must be a priority to ensure that urban GI planning leads to sustainable cities.

The social and ecological characteristics of urban residential yards has been the focus of many studies, especially in the past decade (see [8,11]; also reviewed in [12,13]). Floristic analyses for residential yards in many cities suggest that these areas support high levels of biodiversity [14-17], and especially non-native ornamental species [18] introduced through a globalized nursery trade [19]. When compared to surrounding native vegetation patches, soil organic carbon storage and available phosphorus are generally higher in urban residential yards [20,21]. Ecological characteristics of urban yards are a product of management practices at the household and neighborhood scales, which are themselves a product of social drivers that operate at multiple hierarchical scales [13,22]. Variation in household-level socio-economic factors such as income and education often can explain dissimilarities in urban biodiversity and certain yard management practices such as yard expenditures and fertilizer use (e.g., [23-25]). Yet these relationships are hardly universal, and may be overridden by factors, feedbacks and processes occurring at the neighborhood or regional scales, which may also operate at different temporal scales (reviewed in [13,22]). Thus, the development of urban greening strategies that target residential lots would be best served with contextual information on the social-ecological factors and processes that may influence residential yard dynamics, and the understanding that these processes will likely transcend the household scale.

Even as urban expansion is increasing world-wide [26], paradoxically many cities around the world, and more frequently in developed countries, have been experiencing rapid de-population [27], a phenomenon often referred to as the "shrinking city" [28,29]. Many studies on shrinking cities have focused on its causes and its large-scale effects on neighborhoods. De-population is frequently connected to economic decline [30], and the loss of residents leads to a huge oversupply of housing units and an increase in vacant lots [31]. Abandonment of neighborhoods eventually leads to a lack of maintenance of infrastructure and subsequently to neighborhood decline [32]. Discussions among urban planners and policymakers on the revitalization of shrinking cities have focused on "right-sizing" cities in decline, i.e., reducing gray infrastructure to fit current population needs and utilizing this process as an opportunity to develop and expand urban GI and the production of ecosystem services [33,34]. However, much of this discussion focuses on processes at the neighborhood or city scales. There is a lack of understanding about how these processes themselves may feed back into the behaviors of those residents that remain, and how these behaviors in turn may influence household-level yard dynamics. Moreover, discussion of shrinking cities and their potential revitalization has been centered on temperate cities (US and Europe) where this phenomenon was first addressed. Yet select cities in other climate zones, such as tropical America, are also declining or anticipated to contract in coming decades, although at rates slower than in the US, Europe, or Japan [35].

In this paper, we provide a synthesis of several social-ecological processes driving residential yard dynamics in the Río Piedras Watershed (RPWS) located in the city of San Juan, Puerto Rico, through the evaluation of empirical findings related to yard management decisions, yard area, and yard services. We emphasize the role of factors occurring at the household scale. Results are discussed within the context of shrinking cities using an integrated, multi-scalar, social-ecological systems framework, and consider the implications of household GI for advancing urban sustainability theory. 


\subsection{Conceptual Model of Household Green Infrastructure of the Rio Piedras Watershed Using a Social-Ecological Systems Approach}

Residential landscapes within the RPWS fit the general conceptual model set forth by a growing body of literature on the nature of residential urban social-ecological systems (SES). Within this framework, SES are portrayed as complex adaptive systems that are strongly influenced by social-ecological factors, generated at the household scale ("bottom-up factors" [11,23]), but can also be influenced, and in some cases strongly so, by "top-down" social-ecological factors [11] operating at other spatial and temporal scales [13,22] such as neighborhood decline [32] and municipal, state or national economic-demographic trends [36,37]. Figure 1 shows a diagrammatic representation that summarizes household GI dynamics in the RPWS.
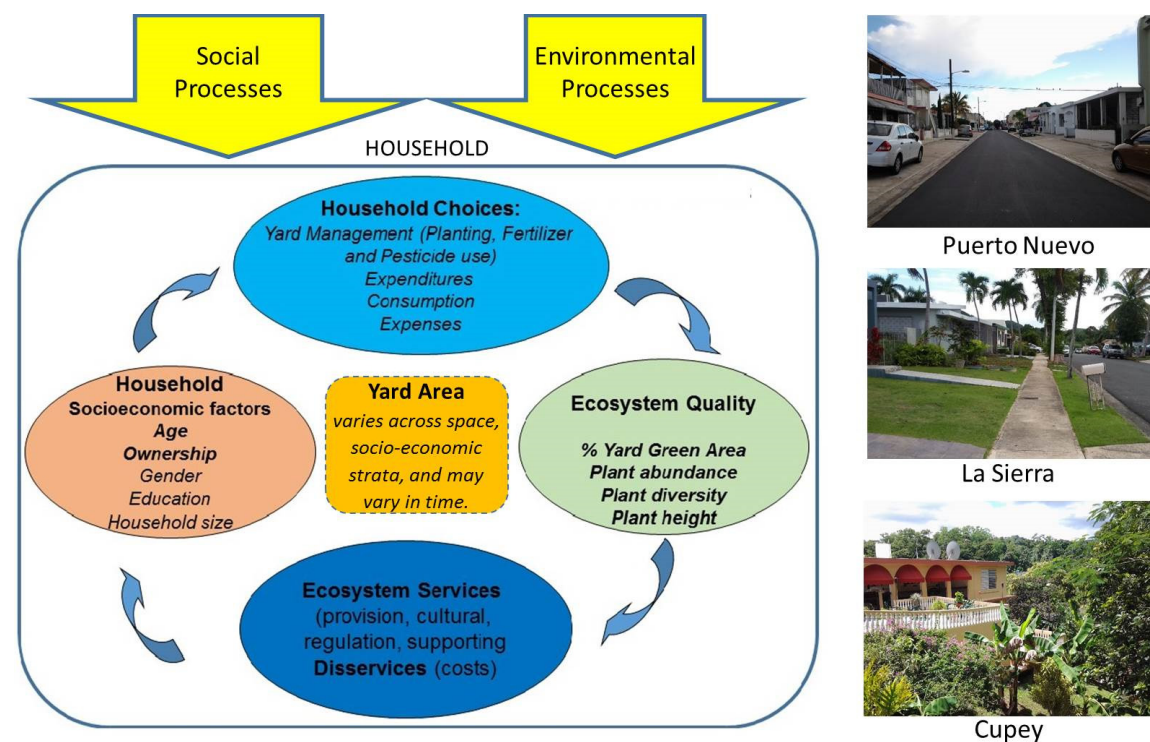

Figure 1. Conceptual model of household green infrastructure (GI) dynamics within the Río Piedras watershed (RPWS) showing primary socio-economic factors affecting household yard GI indicators, and the importance of yard area. Processes inside the blue rectangle are considered "bottom-up" while the external yellow arrows represent "top-down" processes. Accompanying photos show examples of yard types (based on species diversity and structure) at three neighborhoods within the RPWS representing the lower (Puerto Nuevo), middle (La Sierra) and upper watershed (Cupey). Household choices and their association with household socio-economic factors come from results of this study.

At the neighborhood scale, we know that in some areas of San Juan, residential yards have experienced dramatic reductions in pervious surfaces in the last 55 years [38]. At the same time, a recent study showed that residential yards within the watershed hold considerable plant diversity with a flora that is dominated by non-native plants (68\%) and mostly ornamental shrubs [14]. Another study has shown that while yard area is a major driver of plant diversity and abundance (larger yards hold more plants and more species), residents' age and ownership status (owner vs. renter) may also influence yard vegetation diversity and structure (older residents and owners tend to maintain more plants, more trees and more diversity [39]). Yard areas are not equally distributed across residential areas, with the larger yards $\left(>1000 \mathrm{~m}^{2}\right)$ being more frequent in the upper part of the watershed and the smallest ones $\left(<250 \mathrm{~m}^{2}\right)$ in the lower part [39]. Household variables such as household income, years of formal education, household size, gender and household size were also examined and were not related to vegetation structure or composition [39]. These variables are important drivers of GI in many urban systems, especially in temperate areas $[13,22,23]$. Due to its humid subtropical condition, high water availability for yards in San Juan was suggested as a potential explanation for the lack of association between income and the state of GI [39]. 


\section{Materials and Methods}

\subsection{Study Site}

The subtropical (sensu Holdridge [40]) city of San Juan, capital of Puerto Rico, which in 2010 had a population of 395,326 people, has undergone a 9\% population decline since the year 2000 [41,42]. Population loss is an island-wide phenomenon that has been related to off-island emigration [43] as a result of a severely depressed economy and shrinking job markets beginning in 2006 [44]. Depopulation of the San Juan Metropolitan Area also occurs within the context of rapid demographic change toward an ageing population, which has accelerated in response to the emigration of a younger and less educated segment of Puerto Rico's population [43]. The work presented in this study is centered on the RPWS (Figure 2), an urban watershed that has an area of $67,000 \mathrm{~m}^{2}$ and covers most of the municipality of San Juan, in addition to small portions of the municipalities of Guaynabo and Trujillo Alto $[45,46]$. These sites have been the focus of several studies addressing sustainability and GI issues from a social-ecological perspective conducted by the San Juan ULTRA (Urban Long Term Research Area) network (sanjuanultra.org) that was initiated by the U.S. Forest Service and the University of Puerto Rico at Río Piedras [47]. All sites have access to sections of the Río Piedras river, and were chosen because they are representative of the urban-suburban gradient and the social, economic and demographic mosaic within the watershed. Residences on the Puerto Nuevo and Avenida Central sites have yards with the smallest GI indexes (and smaller yards), while residences in the Chiclana and the Caimito site have yards with the largest GI indexes and largest yards [39].

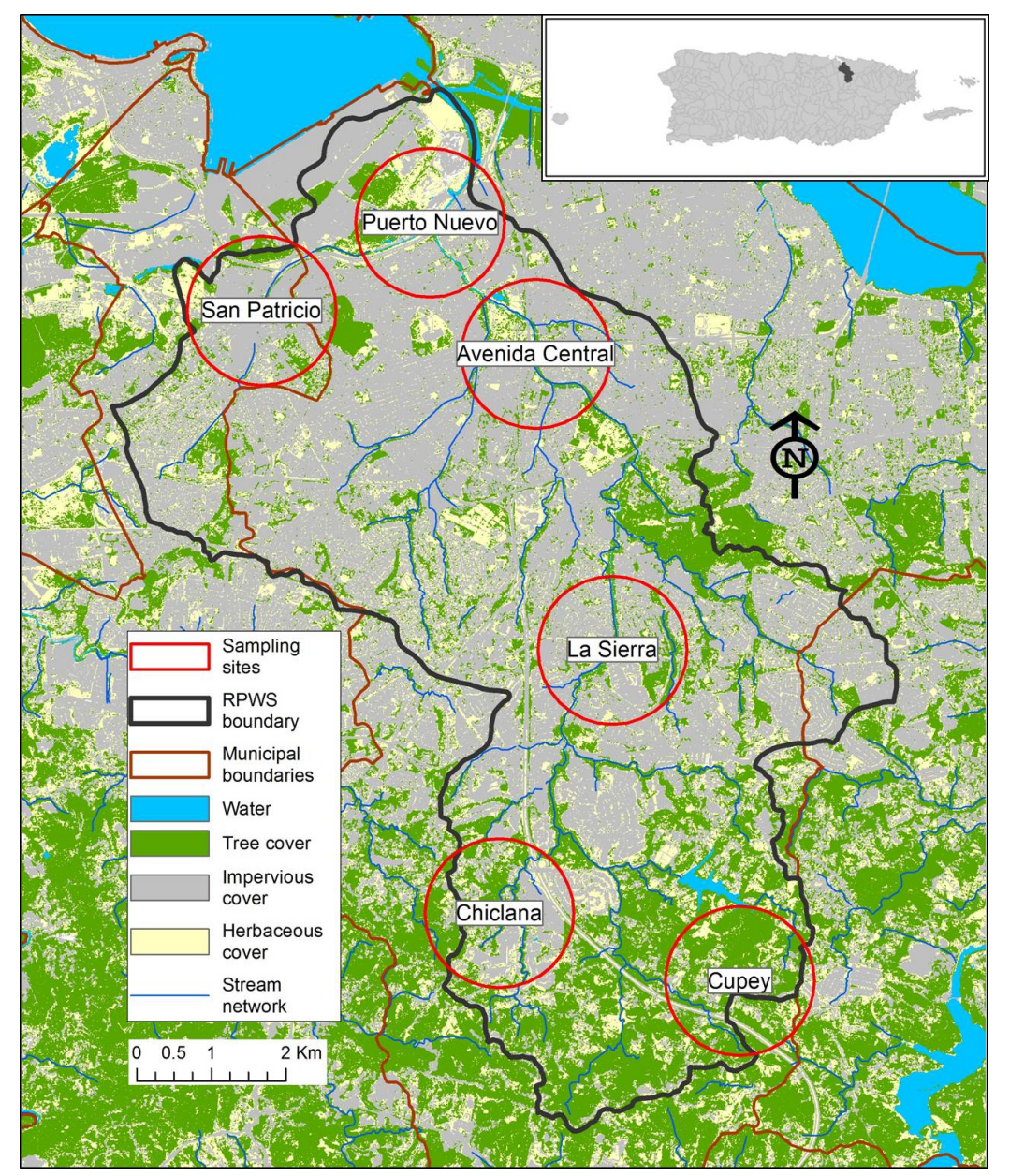

Figure 2. Permanent San Juan Urban Long-Term Research Area (ULTRA) sampling sites for the study of residential areas across the RPWS. 


\subsection{Residential Surveys to Evaluate Yard Management and Services}

Data from this work was generated from two independent residential surveys performed in 2011 and 2013 across six localities within the RPWS: Avenida Central, Chiclana, Cupey, La Sierra, Puerto Nuevo, and San Patricio (Figure 2). These localities are long-term monitoring areas of the San Juan ULTRA network, representative of the social-ecological variation within the RPWS, and originally set up to study household-level dynamics of this urban watershed. The sampling scheme and site selection has been described in detail in several studies $[14,39,48]$. Both surveys used a similar sampling design which aimed to implement between 72 and 81 household questionnaires per site to be answered by the resident responsible for making major household decisions. These surveys addressed questions for a variety of research projects and thus the questions analyzed here represent only a subset of the total number of questions asked within each instrument. From the 2011 survey, we extracted questions related to yard management to evaluate the likelihood that residents would (1) water their yards infrequently ( 0 to once a month) or frequently (more than twice a month); (2) use fertilizers and pesticides; (3) hire out yard maintenance (to individuals or a company). The 2011 survey was also used to record yard area and the cost of yard maintenance. From the 2013 survey, we extracted questions related to (1) yard services (what is the yard used for?); and (2) how likely residents were to make changes to their yards in the next five years. The yard use question was an open question and when applicable, services indicated by residents were categorized following the ecosystem services classification of the Millennium Ecosystem Services Assessment, consisting of provisioning, regulating, cultural, and supporting services [49]. Both surveys included questions about participating households' socio-demographic-economic profile (residents' age, gender, civil status, and years of formal education, house ownership status, household income, and household size). Household socio-economic profiles for the first survey were originally published in Meléndez-Ackerman et al. [39]. Nevertheless, they are presented here again as a means to compare the socio-economic profiles of both surveys (2011 vs. 2013), and because there are slight changes in the number of observations between the previous study and this study due to missing values in the variables evaluated here (see 3. Results). Information collected from these surveys was used to construct data matrices to evaluate the relationship between household socio-economic variables (independent variables) with response variables related to yard maintenance and yard services. Variables were a mixture of numerical and categorical variables with most categorical variables coded as binary variables (see results Tables 1 and 2).

Table 1. Socio-demographic profile of residents for both residential surveys within the Río Piedras watershed.

\begin{tabular}{ccccc}
\hline & & & 2011 Survey (N = 315) & 2013 Survey (N = 285) \\
\hline A & Categorical Variable & Class (Code) & Frequency & Frequency \\
\hline 1 & Gender & Female (1) & 192 & 155 \\
& & Male (0) & 123 & 130 \\
2 & Civil Status & Married (1) & 180 & 178 \\
& Single (0) & 135 & 107 \\
3 & Ownership & Owner (1) & 273 & 258 \\
& & Renter + other (0) & 42 & 27 \\
\hline B & Numerical Variable & Descriptive Statistic & $\mathbf{2 0 1 1}$ Survey Value & $\mathbf{2 0 1 3}$ Survey Value \\
\hline 4 & Age (in years) & Mean \pm SE & $56.2 \pm 18.7$ & $60.4 \pm 17.1$ \\
5 & Years of formal education & Mean \pm SE & $15.3 \pm 4.3$ & $15.1 \pm 3.9$ \\
6 & Household income & Mean \pm SE & $\$ 23,017 \pm \$ 22,271$ & $33,158 \pm 25,623$ \\
7 & Household size & Mean \pm SE & $3.0 \pm 1.6$ & $2.8 \pm 1.4$ \\
\hline
\end{tabular}


Table 2. Descriptive statistics for response variables related to yard maintenance practices and services provided by residential yards in the Río Piedras watershed. Variables "yard changes" and "average number of yard services" were extracted from the 2013 survey. All remaining variables were extracted from the 2011 survey.

\begin{tabular}{cccc}
\hline A. & Categorical Variable & Class (Code) & Frequency \\
\hline 1 & Planting & Yes (1) & 238 \\
& & No $(0)$ & 77 \\
2 & Fertilizer Use & Yes (1) & 151 \\
& & No (0) & 164 \\
3 & Pesticide Use & Yes (1) & 104 \\
& & No (0) & 211 \\
4 & Hired Labor & Yes (1) & 160 \\
& & No (0) & 155 \\
5 & Hired Company & Yes (1) & 29 \\
& & No (0) & 286 \\
6 & Watering Frequency & Twice a month or more (1) & 155 \\
& & Once a month or less $(0)$ & 160 \\
7 & Yard Changes & Yes (1) & 128 \\
& & No (0) & 157 \\
\hline B & Numerical Variable & Descriptive Statistic & $\mathbf{2 0 1 2}$ Survey Value \\
\hline 8 & Average Cost of Maintenance (US\$) & Mean \pm SE & $78.5 \pm 50.6$ \\
9 & Average Number of Yard Services & Mean \pm SE & $1.6 \pm 0.89$ \\
\hline
\end{tabular}

\subsection{Statistical Analyses}

We used binary logistic regression analyses to evaluate the role of social factors (Table 1) at the household scale on the following variables: likelihood of frequent yard watering, likelihood of using fertilizer, likelihood of using pesticides, likelihood of planting in the yards, likelihood of hiring a company and hired labor, and the likelihood of making yard changes in the next five years. We used multiple regression analyses to assess the role of social factors at the household scale on the cost of maintenance and number of services provided by yards. We first followed a process described in Landry and Chakraborty [50] designed to test for spatial dependence within the data using $\mathrm{GeoDa}$ 1.4.1 [51]. The process consisted of testing regression residuals from ordinary least squares (OLS) models for global spatial autocorrelation in the data using Moran's I statistics. None of the spatial autocorrelation analyses were significant. ( $p$ values of I $>0.05$ ), after which we proceeded to use results from OLS regression models.

Logistic and spatial regression analyses included two additional dependent variables in addition to the socio-economic variables. The variable "site" was included as a dummy variable with six categories to account for potential site-effects on the likelihood of responses. The variable "yard area" was also included in the analyses of all response variables extracted from the 2011 survey, to account for the effect of yard size on management decisions. For this variable, we used the log transformation to meet the normality requirements of the OLS regression analysis of the "cost of yard maintenance". Logistic and OLS regression analyses were run in R 3.0.2 [52].

\section{Results}

\subsection{Socio-Economic Profile of Households}

Socio-economic profiles were similar between the surveyed populations in 2011 and 2013 in that there was a slightly higher proportion of females and married residents in our samples, and that a large proportion of residents were owners (over 85\%, Table 1). For both surveys, residents had on average some college education and were on average above 55 years of age (Table 1). 


\subsection{Yard Management Characteristics of Households}

When asked, the majority of residents indicated that they actively planted vegetation in their yards $(76 \%)$ and that they did not use pesticides $(67 \%$; Table 2$)$. Residents did not show a clear preference for the use (or lack of use) of fertilizers (52\% used them), frequency of yard watering (51\% indicated watering more than twice a month), or the use of hired labor (51\% of residents indicated hiring individuals) as part of their yard maintenance practices (Table 2). Only a small percentage of residents $(9 \%)$ contracted a landscaping company to perform yard maintenance. Average costs of monthly yard maintenance were below 79 US\$. Only $45 \%$ of residents expressed that they would make changes in their yards within the next five years.

Several yard management variables (likelihood of planting, fertilizer and pesticide use, and hiring labor) were associated with household socio-economic variables, yet the relationships were not equivalent across yard management variables (Table 3). The likelihood of planting vegetation was influenced by gender, years of formal education, and yard area. The likelihood of planting vegetation was greater for females than for males, decreased with education, and increased with yard area. For this variable, results also showed a positive significant coefficient for La Sierra, suggesting that the likelihood of planting at this site was higher relative to planting at the reference site (Avenida Central). The likelihood of using fertilizer increased with age and household size, but it was not related to the remaining variables in the model. The likelihood of using pesticides increased with age and years of formal education, but was not associated with other variables in the model. Additionally, years of formal education had a positive effect, and residing in Puerto Nuevo had a negative effect on the use of hired labor for yard maintenance purposes (Table 3). Multiple regression analysis showed that the cost of maintaining yards was positively associated with years of formal education, average income, and yard area (Table 4).

Table 3. Regression coefficients from binomial logistic multiple regression analyses testing the association between household socio-demographic-economic variables and the probability of different resident responses about yard management practices. Coding for gender, civil status and Ownership was as follows: Gender (Female $=1$, Male $=0$ ), Civil Status (Married $=1$, Single and other $=0$ ), Ownership (Owner =1, Renter and other $=0$ ), Site (Reference site $=$ Avenida Central $=0$, All others $=1$.

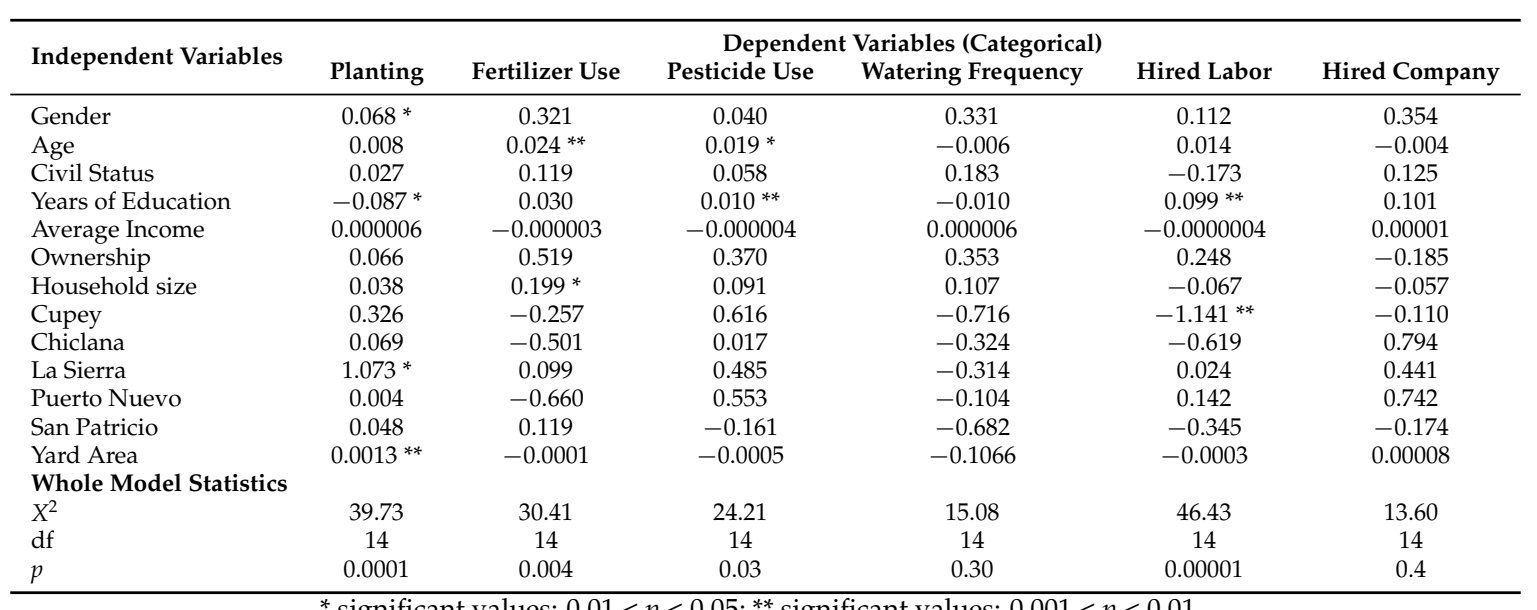

* significant values: $0.01<p<0.05 ;{ }^{* *}$ significant values: $0.001<p<0.01$. 
Table 4. Regression coefficients from ordinary least squares (OLS) regression analyses for "cost of maintenance" and "number of yard services" (dependent variables) per household as a function of household socio-demographic-economic factors (independent variables). The analysis for "cost of maintenance" also included yard area as an explanatory factor which was log-transformed. Site was included as a dummy variable in both analyses to account for potential site-specific effects.

\begin{tabular}{ccc}
\hline Independent Variables & $\begin{array}{c}\text { Cost of Yard Maintenance } \\
\text { From 2011 Survey }\end{array}$ & $\begin{array}{c}\text { Number of Yard Services } \\
\text { From 2013 Survey }\end{array}$ \\
\hline Gender & -2.435 & -0.017 \\
Age & 0.150 & 0.006 \\
Civil Status & 3.830 & 0.111 \\
Years of Formal Education & $2.051^{*}$ & 0.023 \\
Average Income & $0.0004^{*}$ & 0.0000001 \\
Ownership & 7.071 & $0.518^{*}$ \\
Household size & 0.260 & -0.028 \\
Site & 2.842 & -0.010 \\
Log(Yard Area) & $19.43^{*}$ & - \\
\hline Whole Model Statistics & & \\
$F$ & 5.63 & 2.341 \\
df & 9305 & 8276 \\
$p$ & 0.000003 & 0.01898 \\
$R^{2}$ & 0.117 & 0.064 \\
\hline & $*$ significant values $0.001<p<0.01$. &
\end{tabular}

\subsection{Yard Services and Likelihood of Yard Changes}

The surveys indicated that yards provided ten different types of ecosystem services, which were classified into provisioning, cultural, supporting, and regulating services (Figure 3). Cultural and provisioning services were most frequently indicated, with food production ( $72.3 \%$ of households) and recreation and ecotourism services (67.1\% of households) being the most repeatedly mentioned yard services. Less than $18 \%$ of the residents indicated receiving regulating services (disease and climate regulation) from household yards, and $24.4 \%$ specified habitat for wildlife, a supporting service. While the majority of services were associated with GI, about $35.5 \%$ of the households also indicated that the physical space of their yards provided non-ecosystem-related services associated with household tasks such as for storage, car repairs, or washing clothes (Figures 3 and 4a). The majority of respondents $(83.9 \%)$ indicated that yards provided at least one service, $36.7 \%$ of households indicated that yards provided two or more types of services, and $16.1 \%$ of residents indicated that their yards provide no services (Figure $4 \mathrm{~b}$ ). Multiple regression analyses showed there was a positive association in the number of services provided by yards with ownership (Table 4). Upon examining the likelihood of indicating different service types (provisioning, regulating, cultural, supporting, and household chores), only likelihood of mentioning cultural and supporting services showed significant associations with household socio-economic variables (Table 5). Specifically, the likelihood of mentioning that yards provided cultural services was positively associated with the respondents' education and ownership, and the likelihood of mentioning that yards provided supporting services was positively associated with ownership. Additionally, residents from Chiclana were more likely to express that yards provided cultural services than residents from Avenida Central (the reference site). 


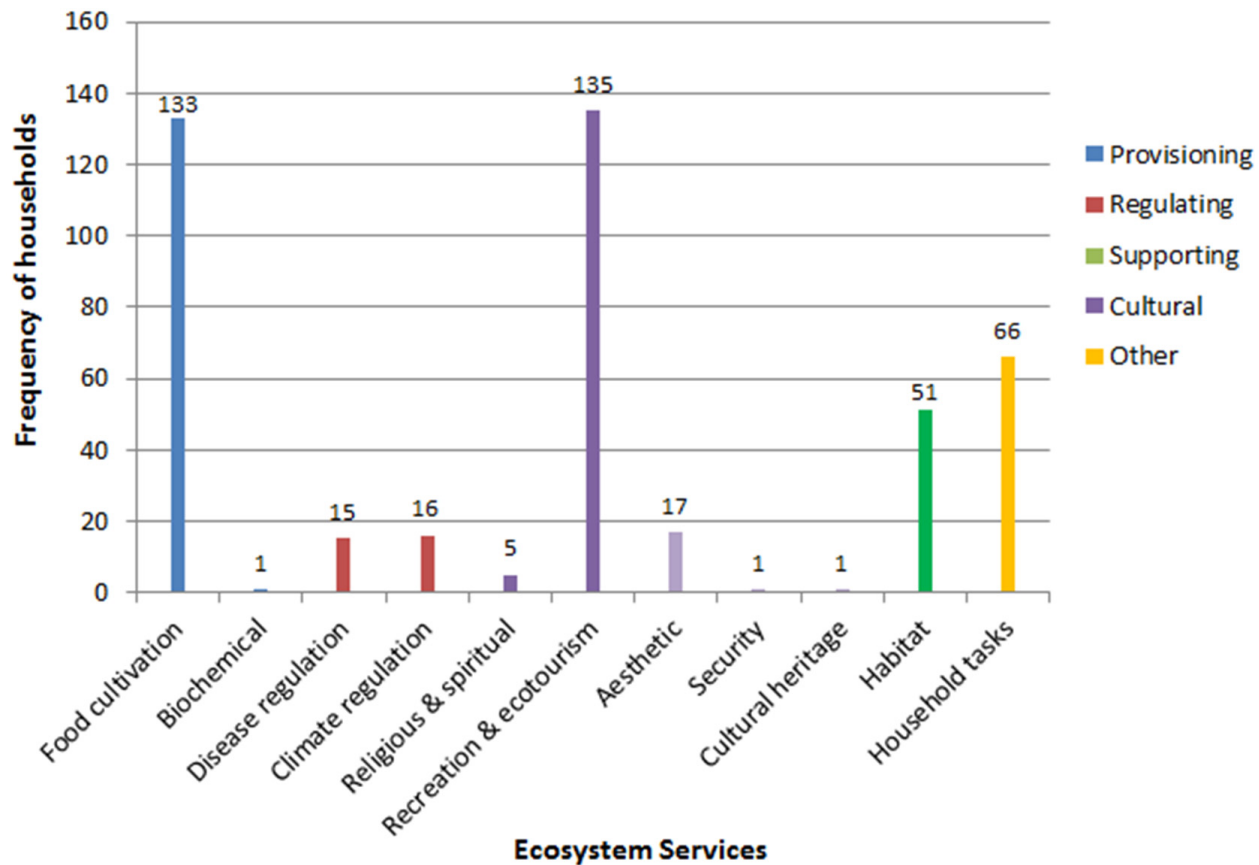

Figure 3. Frequency distribution of resident responses on the different types of services provided by residential yards in the Río Piedras watershed. Categories are not mutually exclusive and represent the frequency of responses for each service. Data was derived from responses to the open question: what do you use your yard for? Responses included in "other" represent yard uses not considered to be ecosystems services (e.g., storage, car repairs).
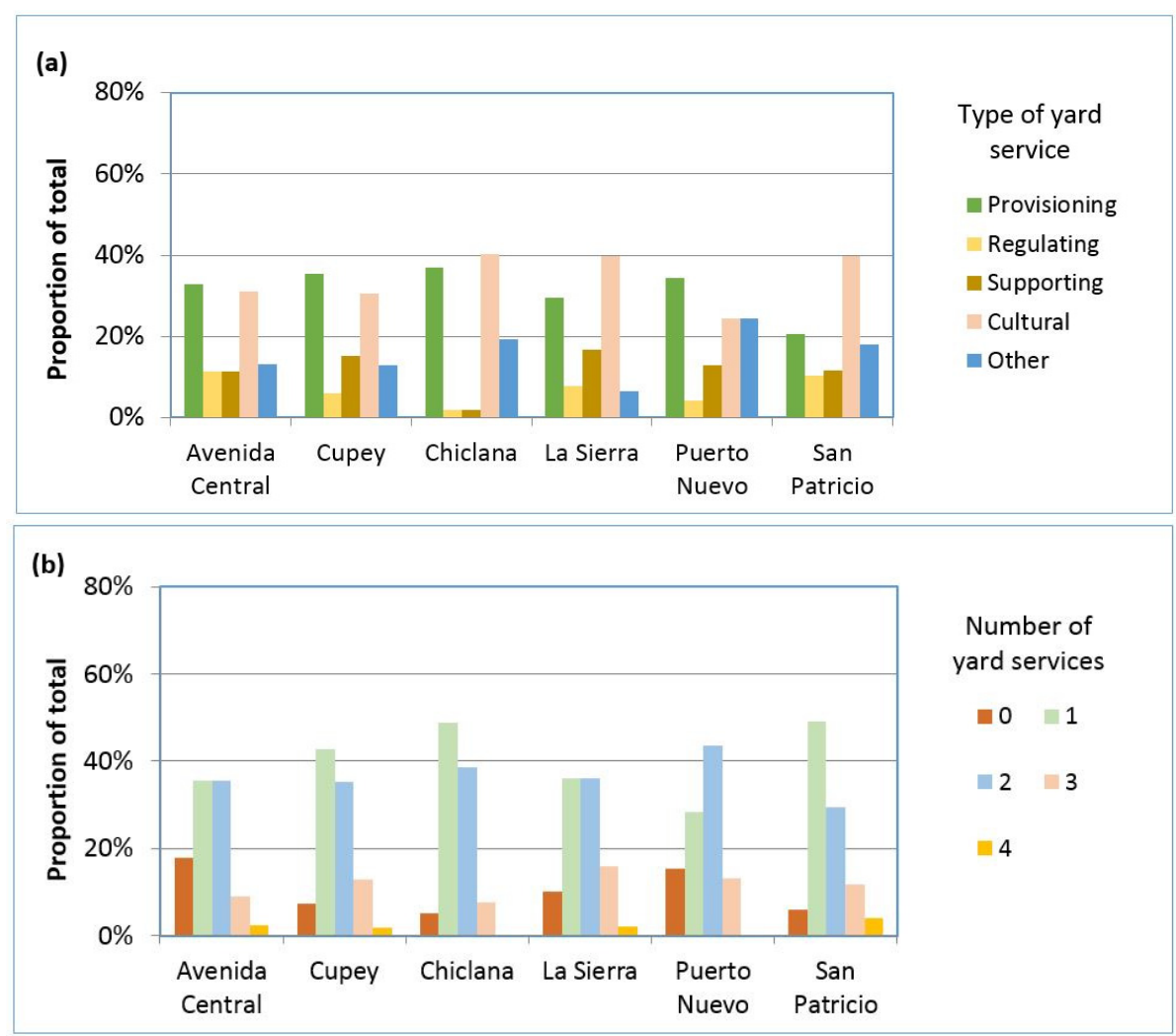

Figure 4. Cont. 


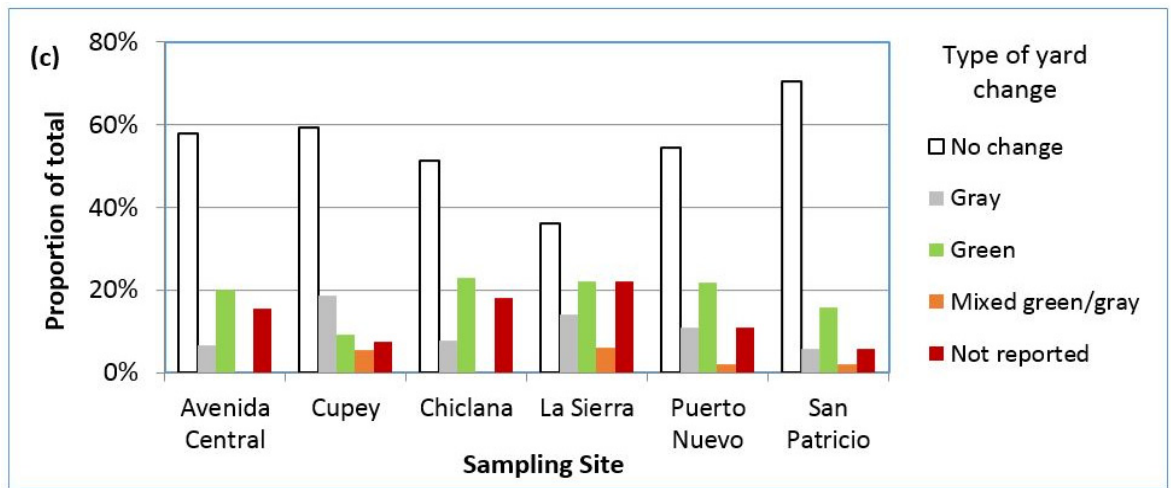

Figure 4. Frequency distribution of residential yard services and expected yard changes across sites within the Río Piedras watershed. (a) Frequency of yard service categories; (b) number of yard services per household; (c) resident responses about yard change.

Table 5. Regression coefficients from binomial logistic multiple regression analyses testing the association between household socio-demographic-economic variables and the probability of different resident responses about making changes to yards and obtaining the following services from yards: (1) Cultural (recreation, spiritual, aesthetic); (2) Provision (food/biochemical); (3) Regulation (disease and climate regulation); (4) Supporting (habitat for wildlife); (5) Household chores. Coding for gender, civil status, Ownership and site was as follows: Gender (Female $=1$, Male $=0$ ), Civil Status (Married = 1, Single and other $=0)$, Ownership (Owner $=1$, Renter and other $=0)$, Site (Reference site = Avenida Central $=0$, All others $=1$ ).

\begin{tabular}{|c|c|c|c|c|c|c|}
\hline $\begin{array}{l}\text { Independent } \\
\text { Variables }\end{array}$ & Cultural & Provisioning & Regulating & Supporting & $\begin{array}{l}\text { Household } \\
\text { Chores }\end{array}$ & $\begin{array}{l}\text { Yard Changes } \\
\text { in } 5 \text { Years }\end{array}$ \\
\hline Gender & 0.289 & -0.282 & -0.324 & 0.285 & -0.034 & -0.067 \\
\hline Age & 0.006 & 0.006 & 0.019 & -0.021 & $0.028^{*}$ & $-0.044^{* * *}$ \\
\hline Civil Status & -0.027 & 0.354 & 0.034 & -0.200 & 0.177 & -0.004 \\
\hline Years of Education & 0.090 * & 0.036 & -0.038 & 0.097 & -0.035 & $0.016^{*}$ \\
\hline Average Income & 0.00001 & -0.000004 & -0.00000001 & 0.0000008 & -0.000009 & $\begin{array}{c}0.013 \\
-0.00002 * *\end{array}$ \\
\hline Ownership & $1.501 * *$ & 0.637 & -0.361 & $1.528 *$ & -0.124 & 0.692 \\
\hline Household size & 0.128 & -0.167 & 0.044 & 0.005 & 0.224 & 0.093 \\
\hline Cupey & 0.915 & 0.446 & -0.750 & 0.961 & -0.033 & -0.206 \\
\hline Chiclana & $1.068 *$ & 0.373 & -2.224 & -1.614 & 0.149 & -0.321 \\
\hline La Sierra & 0.813 & -0.036 & -0.343 & 0.693 & -0.770 & 0.845 \\
\hline Puerto Nuevo & 0.355 & 0.436 & -1.172 & 0.723 & 0.744 & 0.116 \\
\hline San Patricio & 0.630 & -0.691 & -0.069 & 0.234 & 0.553 & -0.398 \\
\hline \multicolumn{7}{|c|}{ Whole Model Statistics } \\
\hline$X^{2}$ & 36.4 & 19.33 & 10.84 & 27.7 & 27.53 & 54.16 \\
\hline $\mathrm{df}$ & 13 & 13 & 13 & 13 & 13 & 13 \\
\hline$p$ & 0.0003 & 0.08 & 0.54 & 0.006 & 0.006 & 0.0000003 \\
\hline
\end{tabular}

Logistic regression showed some significant associations between the likelihood of making changes to yards within the next five years and household socio-economic factors (Table 5). The likelihood of making changes was positively associated with years of formal education, but negatively associated with age and income (Table 5). Post-hoc logistic regression analysis of the household factors influencing changes toward an increase in gray infrastructure showed a significant regression coefficient for income $(-0.00003, p=0.01)$ and education $(0.14, p=0.06)$, but the test of the full model was marginally non-significant $X^{2}=19.7, \mathrm{df}=12, p=0.07$ ). The same analysis evaluating the probability that residents would make changes that involved GI improvement showed a significant effect of age $(-0.03, p<0.001)$ on the probability of responses (full model $\left.X^{2}=29.0, \mathrm{df}=12, p=0.006\right)$. In other words, younger residents are more likely to make green improvements than older ones. 


\section{Discussion}

\subsection{Sustainability and Yard Management}

Current sustainability discourse emphasizes the use of GI strategies as a way to increase urban adaptive capacity and resilience through the provision of a wide variety of ecosystem services $[53,54]$. Given that a large portion of urban GI is in private residential yards $[7,8]$, these areas can make important contributions to urban sustainability if managed properly. Recommended management practices for bolstering sustainability in residential yards often include strategies that minimize the ecological footprint of households, as well as the planting of trees and woody vegetation, the use of native and food species, and dematerialization (material flows in closed cycles) approaches that lead to a limited use of pesticides, fertilizers and water [55]. These strategies often aim to maximize the provision of multiple ecosystem services to achieve human well-being, which aligns with sustainability goals [56]. We use results from this and other studies by the San Juan ULTRA network to provide an overview of the current management and ecological characteristics of residential yards, and the nature and drivers of yard management decisions in the RPWS within the shrinking city of San Juan, Puerto Rico. This information helps us evaluate how consistent contemporary management practices with current urban sustainability theory are, and is a first step towards identifying which processes at the household scale may contribute to observed trends.

\subsection{What Are the Yard Services in the Río Piedras Watershed?}

Most residents we surveyed in the RPWS viewed their yards as a functional space providing a variety of services, with food and cultural services being the most frequently acknowledged. Food provision is a yard service related to GI $[57,58]$, but prior studies suggest that its importance is variable across the watershed we examined [14,59]. On average, $36 \%$ of watershed households obtain food products from their yards, but the rate of this occurrence is more frequent in the upper watershed where yards are larger [59]. Our results, while emphasizing that yards do have an important role in residential living for most households, also show that $40 \%$ of residents do not view these spaces as multifunctional. This finding suggests that the notion advocated by modern urban planning theories that multifunctionality of spaces is a desirable trait (e.g., new urbanisms, smart growth, multifunctional land use [60]), which is an inherent component of the GI concept as applied to cities [2], is not yet widely perceived by residents in San Juan. Moreover, at both the site and watershed scales, there seems to be a disparity in the types of ecosystem services provided by yards, with supporting or regulating services being less frequently mentioned than provisioning and cultural services. This disparity is important from the management perspective, because funding and strategic planning for GI often focuses on these less recognized services (e.g., [56,61]). It is also important to recognize that many residents indicated receiving yard services not necessarily related to ecosystem services provided by GI, but rather related to the facilitation of household chores. Furthermore, the frequency of yard services was not equally distributed across residential localities. Consider, for example, the Puerto Nuevo site and San Patricio: In Puerto Nuevo, where yards have a higher rate of gray cover relative to other surveyed residential areas in the watershed [39], "other" non-ecosystem-related uses for storage and car repairs were more common than cultural services. In comparison, residents in San Patricio, a housing development that lies next to a protected urban forest, more frequently mentioned cultural services (Figure 4).

\subsection{What Are the Drivers of Yard Structure and Management in San Juan?}

This study has shown positive associations between the probability of fertilizer and pesticide use with resident's age which may promote yard greening. Prior studies in this city have shown positive associations between plant abundance, diversity, tree density and percent yard green areas with resident's age [39]. On the other hand, in this study, older residents were less likely to make yard changes and yard planting was not influenced by age. This suggests that positive correlations between 
age and yard plant abundance, diversity and percent green areas do not necessarily result from an active engagement of older age groups in yard greening, and may come from reduced maintenance or abandonment. Yard greenness variables within residential yards in San Juan have been shown to be positively correlated with household ownership [39]. Considering that Meléndez-Ackerman et al. [39] found a positive relationship between yard greenness and ownership, observed positive correlations between the total number of services provided by yards and the provision of cultural and supporting yard services to residents with house ownership (this study) is an expected outcome The outcome is also supported by the widespread assumption that there is a positive relationship (even if nonlinear) between the amount of green cover and biodiversity with ecosystem services provision $[49,62,63]$.

Another finding from this study is that variation in gender seems to influence the probability of planting. Female residents with fewer years of formal education were more likely to respond that planting was an activity that they performed. Gender relations associated with the division of household duties have been a topic of intensive research in the social sciences [64,65], but which gender is most responsible for outdoor work such as planting seems highly heterogeneous and dependent on the socio-economic context. Women are the dominant caretaker of yards in rural areas of developing countries where yards are referred to as "home gardens" and are often a cornerstone to the household's economy [66]. In urban areas of Latin America (including Puerto Rico), past studies agreed on the occurrence of a gender-based division of household chores, but instead women seem to be entrusted with chores inside the house and men to chores outside the house (including yard and plant care, reviewed in [67]). Our study presents a contrasting pattern of what used to be the trend in an urbanized Puerto Rico and Latin America at least fifteen years ago [67]. Which factors are contributing to these differences in female roles with respect to yard planting is not clear, but it seems that they are dynamic and would need further study to fully understand them.

The combined results of this study indicate that the level of formal education has a complex relationship with yard management practices and one that appears to be related to household economics in indirect ways. For example, residents with more formal education and higher incomes spend more money on yard maintenance. Activities such as the use of hired labor and application of pesticides (both of which would add to yard maintenance costs) were more common among residents with more formal education. Even when the effect of income was not detected for these yard management activities, its effects cannot be completely ruled out, as income and education were moderately correlated $(r=0.5)$. An added complexity on the role of education is the fact that even when the probability of providing cultural services by yards was higher among residents with more years of formal education, the likelihood of planting vegetation was not. One possibility is that the provision of cultural services comes at the expense of reducing yard vegetation abundance (i.e., fewer plants), and that there are trade-offs between cultural services and other services (including those from gray infrastructure). For example, maintenance of trees around electric lines in hurricane-prone areas like Puerto Rico is an issue of concern than could lead to trade-offs; pruning trees located in private yards to provide clearance from electric lines may reduce crown height, overall leaf area and biomass $[68,69]$ and consequently the ecological services provided by those trees. Another possibility is that there is no direct linkage between the recognition of services and the quantity of plants. We know that the potential for trade-offs between GI services is an issue of concern in natural resource management as a factor that may detract from GI goals [70,71]. Perceptions of vegetation in public spaces as a dis-amenity (or dis-service) because of security and maintenance concerns has been shown to occur within RPWS [72]. Of significance here is the fact that those residents with more formal education also expressed greater likelihood to make changes in their yards. More importantly, those with additional formal education and income were more likely to make interventions that involve green to gray conversions. These results make explorations of trade-offs even more critical.

Even when we found significant associations between social factors at the household scale (gender, household size, education, income) and some management decisions, past research in this same study area has failed to find similar associations between these factors and the state of GI at the residential 
scale [39]. This suggests the presence of conditions that may override the role of some socio-economic characteristics of households on the biophysical state of yards at RPWS. At the same time, even when significant, the strength of associations between household-level socio-economic factors and management decisions was often weak as indicated with the magnitude of their correlation coefficients and low model fit. To the extent that other system variables (external or internal) in the system are more important then, the role of household-level social factors at shaping GI may be modified. Yard area may be such a variable. For example, the cost of yard maintenance increases with yard area which could create trade-off conditions in this system if the demand for smaller yards were to increase and development interests catered to these demands. Differences in lot sizes and yard area in Puerto Rican cities are also a function of laws and construction regulations, which are themselves guided by urban zoning categories and subject to changes driven by evolution of the international building code, among other things (e.g., Commonwealth of Puerto Rico 1999 [73]; Commonwealth of Puerto Rico 2011 [74]). In the RPWS, larger yards result in yards with increased GI (larger percent green space, more plants, taller trees, and more diversity) [39]. Thus, yard area is an important factor to consider when evaluating and planning GI.

Yard area has also been subject to temporal changes associated with urban, economic and population transformations on the island. Between 1940 and 1970 the landscape of San Juan was transformed from compact urban centers and scattered rural settlements into a suburban patchwork of low- to medium-density single-family housing. During this period, Puerto Rico underwent a social, economic and ultimately urban change, more than tripling its urban population from 566,357 in 1940 to $1,575,491$ by 1970 . A suburbanization process resulted from population shifts, increased housing demand, a new central (state-run) planning approach that promoted and regulated this type of land use model, the development of new infrastructure, and guarantied housing financing [75]. Of these top down dynamics the policies structured by the Puerto Rico Planning Board (established in 1942) had the effect of excluding or prohibiting the building of structures other than single family housing in a 300-meter lot [75]. Beyond the first suburbanization period, however, lot and housing sizes have varied. Third generation suburban areas in San Juan present a stark contrast with those built during the 1940s. These represent larger housing and lot areas and as well as private spaces with greater proportions of green cover [39]. Past work has shown strong spatial variation in yard area. Houses in the lowest portion of the watershed have on average smaller yards relative to those in the upper watershed [39]. Spatial differences in yard area across residential sites are most likely related to historical differences in urban residential developments and potential differences in the rate of residential green area loss across the watershed. The lowest portion of the watershed contains the oldest residential sites. Developed in 1948, the Puerto Nuevo residential project was the first large-scale modern residential development in Puerto Rico and started the current model of urban sprawl where developers seek undeveloped agricultural areas that can be turned into residential projects [76]. Residences in Puerto Nuevo were originally designed with very small dwelling sizes (250-300 $\mathrm{m}^{2}$ [76]) in comparison with the average dwelling sizes by today's standards. This site has also experienced significant losses of residential green areas through conversion of green spaces to built ones [77], and at rates that are much higher relative to other residential areas across the lower watershed. These were generated by a need to increase gray infrastructure amenities (living/parking space), and by neighborhood decline processes that created a demand for additional household income through the rental of living space at a time when the population of Puerto Rico was growing [38]. At the same time, residential areas in the upper portion of the RPWS are a mixture of third generation residential developments and lower density housing that resulted from subdivisions of old farms among relatives and which often have much larger yards than those in high-density residential developments [39]. These greener spaces are a factor in determining housing values within the RPWS [78]. In this way, yard area, and the trade-offs associated with GI-yard area relationships, may dominate over social attributes regarding gender, education, income, and household size in influencing the vegetation abundance and structure of residential yards. 
Aside from the obvious differences in yard area, the combined results for this and other studies point to the presence of processes that vary across geographic contexts and that may also influence yard management and GI, leading to patterns that emerge at the neighborhood scale. For example, Puerto Nuevo is the urban development in our study with the smallest yards and the least amount of green area, and was both the site where residents were least likely to hire labor for yard management, and where yard uses not related to GI were more frequently mentioned (Figure 2). La Sierra, with the highest frequency of residents who do yard planting, hosts a coalition of neighborhoods that is engaged in the active planting of trees along the Arboretum of Cupey, an urban riparian forest that was incorporated into the San Juan Ecological Corridor, a protected urban forest under Law 206 of 2003 [79]. We also know from past work that these riparian corridors have had positive effects on housing prices within RPWS [72]. San Patricio and La Sierra showed lower frequencies of households with provisioning yard services (Figure 4). Both sites are adjacent to highly accessible protected urban forest areas with high abundance of food plants (personal observation), which may compensate for provisioning services that would otherwise come from yards. Spatial differences at the neighborhood scales may result from aggregate behaviors that are derived from a combination of mechanisms that have been addressed theoretically for residential social-ecological systems. These may include, but are not limited to, the existence of spatially variable social norms, housing development codes, environmentally distinct contexts $[13,23]$, and / or variable levels of institutional governance of the built environment across socio-economic strata [39,77].

\subsection{What Are the Sustainability Implications of Current Yard Management and Ecological Characteristics in the Shrinking City of San Juan?}

Shrinking cities present economic and fiscal challenges for governments and their populations. As economic activity falls, possible sources of revenue are compromised. This entails that city governments suffer reduced capacity to access the necessary funds to ensure the provision of enjoyable spaces, such as green areas and recreational facilities, and to attract the necessary investment to develop vacant lots $[80,81]$. However, shrinking cities have also been viewed as fertile ground by which city governments and communities can jointly engage in revitalization efforts that can result in greener and more enjoyable spaces, including land banking to acquire vacant lots and consensus approaches to define greening plans [82]. While such collective efforts can yield positive results, individual household activities, when guided by principles of sustainability, may improve the function of yards and serve as complementary strategies that would hasten a more sustainable and resilient form of development.

Our results indicate that vegetation planting is a common activity of San Juan households. Environmental management studies suggest that predisposition towards pro-environmental behaviors could improve the chances of environmentally-favorable interventions $[83,84]$. Thus, the observed predisposition towards vegetation planting not only has the potential to make positive contributions to residential GI, but could also be a social asset that can facilitate engagement of residents in current and future planting initiatives at the residential scale. Prior analyses addressing the state of the residential GI in San Juan show that these spaces have high levels of plant diversity, and for certain plant groups that diversity is higher than what is found in urban natural areas [14], suggesting that planting has an important influence of the state of that GI. Vila-Ruiz et al. [14] found that yards in the RPWS were dominated by ornamental and non-native shrubs, and food plants comprised $15 \%$ of stems and appeared in at least $25 \%$ of households surveyed, and more frequently in backyards than in front yards.

Responses on watering frequency and use of fertilizers and pesticides suggest that the material inputs into San Juan yards may be at a lower range when compared to many other US jurisdictions. We know that for Puerto Rico, the residential water consumption for outdoor purposes has been estimated at only $20 \%$ [85], which is lower than the US average (30\% [86]). Given that $50 \%$ of residents in our study indicated watering either once a month or never, a $20 \%$ outdoor estimate of residential outdoor water use for Puerto Rico is likely to be an overestimation of current outdoor water use in San Juan. The residential use of fertilizers and pesticides by San Juan residents also seems less 
frequent than in many other US cities. The percentage of residents using fertilizers in San Juan was $47.9 \%$ vs. a range of $50 \%-90 \%$ in at least 11 other US jurisdictions [87-90]. The proportion of residents applying pesticides in San Juan was 33.0\% vs. much higher fractions of $50 \%-75.3 \%$ reported in the mainland US [91,92]. Addition of fertilizers and pesticides add to maintenance costs, which for the RPWS are less than US\$77, half the average spent by US homeowners [93]. From a sustainability and ecological quality perspective, moderate inputs of fertilizers and pesticides for San Juan yards are encouraging, given their potential to pollute urban surface and ground waters [94] and the associated human health concerns [95]. Meléndez-Ackerman et al. [39] suggested that the bioclimatic context of this subtropical city was a factor contributing to reduced water use relative to what is reported as outdoor residential use in the US, owing to a relatively high annual rainfall in San Juan that averages from 1509 to $1755 \mathrm{~mm}$ [45]. While we do not know which factors lead to decreased fertilizer use in San Juan relative to other metropolitan areas, the role of difference in bioclimatic setting is again a possibility.

These dynamics of household GI take on additional meaning in cities like San Juan that are currently experiencing shrinking conditions. Some of the most dramatic changes between the 2000 and 2010 censuses include a 6.1\% increase in Puerto Rico's population of individuals 55 years and older [41,42], and in San Juan a decrease in home ownership from 55.6\% to 54.6\% in concert with a loss of 39,048 residents [96,97], with trends still ongoing [44]. Because resident age and house ownership are positively related to vegetation abundance and diversity [39], one hypothesis is that these socio-demographic changes may lead to both localized increases and decreases in GI. However, consideration of these trends using an integrated SES framework suggests that the answer is not as simple, because yard area remains the main factor influencing yard vegetation and abundance, and yard area may be partially controlled by top down factors that may be influenced by temporal changes in internal or external factors in the city [38,77]. For instance, top-down redevelopment agendas at the municipal level have proposed altering green area configurations and zoning codes in San Juan through densification efforts (e.g., Bahia Urbana Project, The Resonance Report [98]; Proyecto Rio 2012, described in Act No 39 (B. S. 11), see [99]). Bottom-up efforts have also led to top-down action leading to the elimination of residential green areas to make way for additional parking spaces [38]. In a shrinking city context, such top-down effects may become less important than socio-demographic impacts, as the number of vacant housing units increases and the real estate market declines, as has been the case for Puerto Rico in the last five years $[44,100]$.

Housing abandonment that commonly occurs in shrinking cities [28,31] may create conditions where GI is not maintained, increasing green cover independent of yard area. Depopulation of the island has occurred through a combination of reduced fertility rates and high rates of emigration off-island [101]. A former concern about this system was the potential for a "brain drain" [101], but the most recent study using census data rejects this idea and instead indicates that population reductions between 2000 and 2010 were significantly higher among social groups that were younger and with less formal education [43]. Based on these demographic trends, our findings would suggest developments in future yard management where residents would do less planting themselves, and instead rely more on hired labor and increased pesticide use. However, expected decline in average household incomes or increases in unemployment as a result of economic downturn may override these processes through their anticipated interaction with yard expenditures. Property taxes may play a role as well. A very large study in New England with over 36,000 houses found that property taxes may be positively influenced (although moderately so) by residential lot sizes [102]. Thus, the question arises as to whether an increase in property taxes may result from larger lot (and yard areas) in San Juan and discourage development and purchases of housing with large lots. This possibility notwithstanding, property taxes are not expected to be a critical factor in this city given the present tax structure, where a significant number of property owners do not currently pay property taxes; properties are valued at 1958 prices and a large number are altogether exonerated [103]). The complexity and intertwined nature of these factors highlights the need for additional research that addresses changes in the 
management of yard systems from an integrated perspective across multiple scales, including the household level.

\section{Conclusions}

The combined results from this and other studies shed light on the dominant yard ecosystem services perceived by residents in the Río Piedras watershed, and the suite of interactions that may influence yard spaces. The complexity of our findings emphasizes the need to evaluate these systems using multi-scalar, social-ecological approaches that integrate drivers of household GI. In the simplest form, these systems are strongly influenced by internal and external factors at different temporal and spatial scales, some of which influence household management decisions and yard ecosystems and even result in emergent social-ecological patterns. This is consistent with models proposed using empirical data for functioning of temperate cities and confirms the applicability of this approach with tropical systems in the study of residential landscapes. Given their dominance in the urban landscape [7,8], and the potential services that in aggregate they can provide [5], promoting yard practices that lead to more diverse and resource efficient green spaces is a common recommendation in the sustainability literature [104,105]. Planning for sustainability may, however, be a challenge when one considers how dynamic and varied yard structure, area, and management practices could be and the multiple factors that could influence them. While our current working model for residential yards does account for the influence of socio-demographic-economic factors on household management decisions, our results suggest that these relationships at the household scale are not always intuitive in terms of their relationships with actual yard dynamics. Moreover, our results also allude to the influence of external factors (demographic, economic) that may override the role of these relationships, which warrants potential revision of our model pending additional in-depth analysis of these drivers. Within that context, our work emphasizes the on-going need to evaluate the complex mechanisms behind observed associations between social and ecological factors in the management and planning of yards within the context of rapid demographic changes. Only then can we improve our understanding of residential landscapes in such a way that we can better foresee unexpected results and generate timely adaptation strategies that engender urban sustainability.

Acknowledgments: This work has been supported by NSF San Juan ULTRA-Ex (DEB-0948507), NSF-IGERT (HRD 00801577) and its program Agents of Change, and CREST-CATEC (HRD-0734826) and The Center for Applied Tropical Ecology and Conservation. We would like to thank Sofia Olivero, Angélica Erazo, Elizabeth Díaz, Khrisia Torres, Pedro Delgado, Alejandra Bonilla, Stella González, Karla Torres, Jessenia Fontánez, Aramis Garay, Carla López-Lloreda, Cristina Vila and Sofyaneli Colón and many graduate and undergraduate students for their help conducting residential surveys, and the residents of the RPWS for their willingness to participate in this study.

Author Contributions: Elvia J. Meléndez-Ackerman and Christopher J. Nytch analyzed the data and conceived and prepared most of the manuscript; Julio C. Verdejo-Ortiz, Luis E. Ramos-Santiago, and Luis E. Santiago-Acevedo contributed excerpts on the discussion; Elvia J. Meléndez-Ackerman, Luis E. Santiago-Acevedo and Raúl Santiago-Bartolomei participated in survey design and execution; Raúl Santiago-Bartolomei and Julio C. Verdejo-Ortiz contributed on data management; Luis E. Ramos-Santiago, Christopher J. Nytch and Elvia J. Meléndez-Ackerman conceived and developed graphic designs; Tischa A. Muñoz-Erickson contributed to the materials and methods and discussion sections, and together with Luis E. Santiago-Acevedo contributed to the development of the application of SES model to shrinking cities. All authors have read and approved the final manuscript.

Conflicts of Interest: The authors declare no conflict of interest.

\section{Abbreviations}

The following abbreviations are used in this manuscript:

GI:

OLS:

RPWS:

Green Infrastructure

San Juan ULTRA: San Juan Urban Long Term Research Areas

US:

United States 


\section{References}

1. Wong, C.P.; Jiang, B.; Kinzig, A.P.; Lee, K.N.; Ouyang, Z. Linking ecosystem characteristics to final ecosystem services for public policy. Ecol. Lett. 2015, 18, 108-118. [CrossRef] [PubMed]

2. McPhearson, T.; Andersson, E.; Elmqvist, T.; Frantzeskaki, N. Resilience of and through urban ecosystem services. Ecosyst. Serv. 2015, 12, 152-156. [CrossRef]

3. Abunnasr, Y.F. Climate Change Adaptation: A Green Infrastructure Planning Framework for Resilient Urban Regions. Doctoral Dissertation, University of Massachussetts, Amherst, MA, USA, 2013.

4. Foster, J.; Lowe, A.; Winkelman, S. The Value of Green Infrastructure for Urban Climate Adaptation. Center for Clean Air Policy, 2011. Available online: http:/ /dev.cakex.org/sites/default/files/Green_Infrastructure_ FINAL.pdf (accessed on 3 May 2016).

5. Goddard, M.A.; Dougill, A.J.; Benton, T.G. Scaling up from gardens: Biodiversity conservation in urban environments. Trends Ecol. Evol. 2010, 25, 90-98. [CrossRef] [PubMed]

6. Ramos-González, O.M. The green areas of San Juan, Puerto Rico. Ecol. Soc. 2014, 19, 21. [CrossRef]

7. Gaston, K.J.; Warren, P.H.; Thompson, K.; Smith, R.M. Urban domestic gardens (IV): The extent of the resource and its associated features. Biodivers. Conserv. 2005, 14, 3327-3349. [CrossRef]

8. Loram, A.; Tratalos, J.; Warren, P.H.; Gaston, K.J. Urban domestic gardens (X): The extent \& structure of the resource in five major cities. Landsc. Ecol. 2007, 22, 601-615.

9. Goddard, M.A.; Dougill, A.J.; Benton, T.G. Why garden for wildlife? Social and ecological drivers, motivations and barriers for biodiversity management in residential landscapes. Ecol. Econ. 2013, 86, 258-273.

10. Cameron, R.W.F.; Blanuša, T.; Taylor, J.E.; Salisbury, A.; Halstead, A.J.; Henricot, B.; Thompson, K. The domestic garden-its contribution to urban green infrastructure. Urban For. Urban Green. 2012, 11, $129-137$. [CrossRef]

11. Kinzig, A.P.; Warren, P.; Martin, C.; Hope, D.; Katti, M. The effects of human socioeconomic status and cultural characteristics on urban patterns of biodiversity. Ecol. Soc. 2005, 10, 23.

12. Cilliers, S.; Siebert, S.; Davoren, E.; Lubbe, R. Social aspects of urban ecology in developing countries, with an emphasis on urban domestic gardens. In Applied Urban Ecology: A Global Framework; Richter, M., Weiland, U., Eds.; Blackwell Publishing LTD: West Sussex, UK, 2012; pp. 123-138.

13. Cook, E.M.; Hall, S.J.; Larson, K.L. Residential landscapes as social-ecological systems: A synthesis of multi-scalar interactions between people and their home environment. Urban Ecosyst. 2012, 15, 19-52. [CrossRef]

14. Vila-Ruiz, C.P.; Meléndez-ackerman, E.; Santiago-bartolomei, R.; Garcia-montiel, D.; Lastra, L.; Cielo, E. Plant species richness and abundance in residential yards across a tropical watershed: Implications for urban sustainability. Ecol. Soc. 2014, 19, 22. [CrossRef]

15. González-García, A.; Sal, A.G. Private urban greenspaces or "patios" as a key element in the urban ecology of tropical central America. Hum. Ecol. 2008, 36, 291-300. [CrossRef]

16. McKinney, M.L. Urbanization as a major cause of biotic homogenization. Biol. Conserv. 2006, 127, $247-260$. [CrossRef]

17. Smith, R.M.; Thompson, K.; Hodgson, J.G.; Warren, P.H.; Gaston, K.J. Urban domestic gardens (IX): Composition and richness of the vascular plant flora, and implications for native biodiversity. Biol. Conserv. 2006, 129, 312-322. [CrossRef]

18. Acar, C.; Acar, H.; Eroğlu, E. Evaluation of ornamental plant resources to urban biodiversity and cultural changing: A case study of residential landscapes in Trabzon city (Turkey). Build. Environ. 2007, 42, $218-229$. [CrossRef]

19. Ignatieva, M. Plant material for urban landscapes in the era of globalization: Roots, challenges and innovative solutions. In Applied Urban Ecology: A Global Framework; Richter, M., Weiland, U., Eds.; John Wiley \& Sons: New York, NY, USA, 2011; pp. 139-151.

20. Pouyat, R.V.; Yesilonis, I.D.; Golubiewski, N.E. A comparison of soil organic carbon stocks between residential turf grass and native soil. Urban Ecosyst. 2009, 12, 45-62. [CrossRef]

21. Jenerette, G.D.; Wu, J.; Grimm, N.B.; Hope, D. Points, patches, and regions: Scaling soil biogeochemical patterns in an urbanized arid ecosystem. Glob. Chang. Biol. 2006, 12, 1532-1544. [CrossRef] 
22. Roy Chowdhury, R.; Larson, K.; Grove, M.; Polsky, C.; Cook, E.; Onsted, J.; Ogden, L. A multi-scalar approach to theorizing socio-ecological dynamics of urban residential landscapes. Cities Environ. 2011, 4. Article 6.

23. Grove, J.M.; Troy, A.R.; O’Neil-Dunne, J.P.M.; Burch, W.R., Jr.; Cadenasso, M.L.; Pickett, S.T.A. Characterization of households and its implications for the vegetation of urban ecosystems. Ecosystems 2006, 9, 578-597. [CrossRef]

24. Zhou, W.; Troy, A.; Grove, M. Modeling residential lawn fertilization practices: Integrating high resolution remote sensing with socioeconomic data. Environ. Manag. 2008, 41, 742-752. [CrossRef] [PubMed]

25. Zhou, W.; Troy, A.; Grove, J.M.; Jenkins, J.C. Can money buy green? Demographic and socioeconomic predictors of lawn-care expenditures and lawn greenness in urban residential areas. Soc. Nat. Resour. 2009, 22, 744-760.

26. United Nations. World Urbanization Prospects: The 2014 Revision, Highlights; Department of Economic and Social Affairs, Population Division: New York, USA, 2014.

27. UN-Habitat. State of the World's Cities 2008-2009: Harmonious Cities; Earthscan: London, UK, 2008.

28. Oswalt, P. Shrinking Cities, Volume 1: International Research; Hatje Cantz Verlag: Ostfildern, Germany, 2005.

29. LaCroix, C.J. Urban agriculture and other green uses: Remaking the shrinking city. Urban Lawyer 2010, 59, 225-285.

30. Audirac, I.; Fol, S.; Martinez-Fernandez, C. Shrinking cities in a time of crisis. Berkeley Plan. J. 2010, $23,51-57$.

31. Haase, D.; Lautenbach, S.; Seppelt, R. Modeling and simulating residential mobility in a shrinking city using an agent-based approach. Environ. Model. Softw. 2010, 25, 1225-1240. [CrossRef]

32. Ryan, B.D. Rightsizing shrinking cities: The urban design dimension. In The City After Abandonment; Dewar, M., Thomas, J., Eds.; University of Pennsylvania Press: Philadelphia, PA, USA, 2012; pp. 268-288.

33. Rybczynski, W.; Linneman, P.D. How to save our shrinking cities. Public Interest 1999, 135, 30-44.

34. Walling, D. Recycling the City. Smart Growth Network: National Conversation on the Future of Our Communities. 2013. Available online: http://citeseerx.ist.psu.edu/viewdoc/download?doi=10.1.1.396. 7678\&rep=rep1\&type=pdf (accessed on 3 May 2016).

35. UN-Habitat. State of the World's Cities 2012/2013: Prosperity of Cities; Routledge: New York, NY, USA, 2013.

36. Grimm, N.B.; Grove, J.G.; Pickett, S.T.A.; Redman, C.L. Integrated Approaches to Long-Term Studies of Urban Ecological Systems Urban ecological systems present multiple challenges to ecologists-pervasive human impact and extreme heterogeneity of cities, and the need to integrate social and ecological approache. Bioscience 2000, 50, 571-584. [CrossRef]

37. Pickett, S.T.A.; Cadenasso, M.L.; Grove, J.M.; Boone, C.G.; Groffman, P.M.; Irwin, E.; Kaushal, S.S.; Marshall, V.; McGrath, B.P.; Nilon, C.H. Urban ecological systems: Scientific foundations and a decade of progress. J. Environ. Manag. 2011, 92, 331-362. [CrossRef] [PubMed]

38. Ramos-Santiago, L.E.; Villanueva-Cubero, L.; Santiago-Acevedo, L.E.; Rodriguez-Melendez, Y.N. Green area loss in San Juan's inner-ring suburban neighborhoods: A multidisciplinary approach to analyzing green/gray area dynamics. Ecol. Soc. 2014, 19, 4. [CrossRef]

39. Meléndez-Ackerman, E.J.; Santiago-Bartolomei, R.; Vila-Ruiz, C.P.; Santiago, L.E.; García-montiel, D.; Verdejo-Ortiz, J.C.; Manrique-Hernández, H.; Hernández-Calo, E. Socioeconomic drivers of yard sustainable practices in a tropical city. Ecol. Soc. 2014, 19, 20. [CrossRef]

40. Holdridge, L.R. Life Zone Ecology; Tropical Science Center: San José, Costa Rica, 1967.

41. U.S. Census Bureau. P1 Total Population Census 2000, Summary File 1. American FactFinder. 2000. Available online: https:/ /www.census.gov/prod/cen2000/doc/sf1.pdf (accessed on 3 May 2016).

42. U.S. Census Bureau. P1 Total Population Census 2010, Summary File 1. American FactFinder. 2010. Available online: http:/ / www.census.gov/prod/cen2010/doc/sf1.pdf (accessed on 3 May 2016).

43. Abel, J.R.; Deitz, R. The causes and consequences of Puerto Rico's declining population. Fed. Reserv. Bank N. Y. Second Dist. Highlights Curr. Issues Econ. Financ. 2014, 20, 1-8.

44. Federal Reserve Bank of New York. An Update on the Competitiveness of Puerto Rico's Economy. 2014. Available online: https://www.newyorkfed.org/medialibrary/media/outreach-and-education/puertorico/2014/Puerto-Rico-Report-2014.pdf (accessed on 3 May 2016).

45. Lugo, A.E.; González, O.M.R.; Pedraza, C.R. The Río Piedras Watershed and Its Surrounding Environment; International Institute for Tropical Forestry USDA Forest Service: San Juan, Puerto Rico, 2011.

46. De Jesús-Crespo, R.; Ramírez, A. Effects of urbanization on stream physicochemistry and macroinvertebrate assemblages in a tropical urban watershed in Puerto Rico. J. N. Am. Benthol. Soc. 2011, 30, 739-750. [CrossRef] 
47. Muñoz-Erickson, T.A.; Lugo, A.E.; Meléndez-Ackerman, E.; Santiago-Acevedo, L.E.; Seguinot-Barbosa, J.; Méndez-Lázaro, P.; Hall, M.; Quintero, B.; Ramírez, A.; García-Montiel, D.; et al. Knowledge to serve the city: Insights from an emerging knowledge-action network to address vulnerability and sustainability in San Juan, Puerto Rico. Cities Environ. 2014, 7. Article 5.

48. Seguinot, J.; Hernández, R. Methodology for a socio-ecological sampling in the Río Piedras Watershed, San Juan, Puerto Rico. La Innov. Geotecnol. 2011, 1, 13.

49. Millenium Ecosystem Assessment. Ecosystems and Human Well-Being: Biodiversity Synthesis; Island Press: Washington, DC, USA, 2005.

50. Landry, S.M.; Chakraborty, J. Street trees and equity: Evaluating the spatial distribution of an urban amenity. Environ. Plan. A 2009, 41, 2651. [CrossRef]

51. Anselin, L.; Syabri, I.; Kho, Y. GeoDa: An introduction to spatial data analysis. Geogr. Anal. 2006, 38, 5-22. [CrossRef]

52. R Core Team. R: A Language and Environment for Statistical Computing; R Foundation for Statistical Computing: Vienna, Austria, 2013.

53. Kramer, M. Enhancing Sustainable Communities with Green Infrastructure. EPA 100-R-14-006. 2014. Available online: www.epa.gov/smartgrowth (accessed on 3 May 2016).

54. European Commission. Building a Green Infrastructure for Europe. Publications Office of the European Union, 2013. Available online: http://ec.europa.eu/environment/nature/ecosystems/docs/green_ infrastructure_broc.pdf (accessed on 3 May 2016).

55. Cross, R.; Spencer, R. Sustainable Gardens; CSIRO Publishing: Collingwood, Australia, 2009.

56. Odefey, J.; Detwiler, S.; Rousseau, K.; Trice, A. Banking on Green: A Look at How Green Infrastructure Can Save Municipalities Money and Provide Economic Benefits Community-Wide. A Joint Report by American Rivers, the Water Environment Federation, the American Society of Landscape Architects and ECONorthwest. 2012. Available online: http://www.americanrivers.org/assets/pdfs/reports-andpublications/banking-on-green-report.pdf (accessed on 3 May 2016).

57. Bolund, P.; Hunhammar, S. Ecosystem services in urban areas. Ecol. Econ. 1999, 29, 293-301. [CrossRef]

58. Benedict, M.A.; McMahon, E.T. Green Infrastructure: Linking Landscapes and Communities; Island Press: Washington, DC, USA, 2012.

59. Garcia-Montiel, D.C.; Verdejo-Ortiz, J.C.; Santiago-Bartolomei, R.; Vila-Ruiz, C.P.; Santiago, L.; Meléndez-Ackerman, E. Food sources and accessibility and waste disposal patterns across an urban tropical watershed: Implications for the flow of materials and energy. Ecol. Soc. 2014, 19, 37. [CrossRef]

60. Vreeker, R.; de Groot, H.L.F.; Verhoef, E.T. Urban multifunctional land use: Theoretical and empirical insights on economies of scale, scope and diversity. Built Environ. 2004, 30, 289-307. [CrossRef]

61. La Duca, A.; Kosco, J. Getting to Green: Paying for Green Infrastructure Financing Options and Resources for Local Decision-Makers. EPA Report 842-R-14-005 Environmental Protection Agency Office of Wetlands, Oceans and Watersheds National Estuary Program. Available online: http://www.epa.gov/sites/ production/files/2015-02/documents/gi_financing_options_12-2014_4.pdf (accessed on 3 May 2016).

62. Gill, S.E.; Handley, J.F.; Ennos, A.R.; Pauleit, S. Adapting cities for climate change: The role of the green infrastructure. Built Environ. 2007, 33, 115-133. [CrossRef]

63. Grêt-Regamey, A.; Rabe, S.; Crespo, R.; Lautenbach, S.; Ryffel, A.; Schlup, B. On the importance of non-linear relationships between landscape patterns and the sustainable provision of ecosystem services. Landsc. Ecol. 2014, 29, 201-212. [CrossRef]

64. Bianchi, S.M.; Milkie, M.A.; Sayer, L.C.; Robinson, J.P. Is anyone doing the housework? Trends in the gender division of household labor. Soc. Forces 2000, 79, 191-228.

65. Bianchi, S.M.; Sayer, L.C.; Milkie, M.A.; Robinson, J.P. Housework: Who did, does or will do it, and how much does it matter? Soc. Forces 2012, 91, 55-63. [CrossRef] [PubMed]

66. Howard-Borjas, P.; Cuijpers, W. Gender relations in local plant genetic resource management and conservation. In Encyclopedia for Life Support Systems: Biotechnology; EOLSS Publishers: Cambridge, UK, 2002.

67. Colón, A.; Mulero, M.; Santiago, L.; Burgos, N. Estirando el peso: Acciones de ajuste y relaciones de genero ante el cierre de fabricas en Puerto Rico; Centro de Investigaciones Sociales de la Universidad de Puerto Rico, Universidad de Puerto Rico Recinto de Rio Piedras: San Juan, Puerto Rico, 2008.

68. Peper, P.J.; McPherson, E.G.; Mori, S.M. Equations for predicting diameter, height, crown width, and leaf area of San Joaquin Valley street trees. J. Arboric. 2001, 27, 306-317. 
69. Stabler, L.B. Management regimes affect woody plant productivity and water use efficiency in an urban desert ecosystem. Urban Ecosyst. 2008, 11, 197-211. [CrossRef]

70. Setälä, H.; Bardgett, R.D.; Birkhofer, K.; Brady, M.; Byrne, L.; de Ruiter, P.C.; De Vries, F.T.; Gardi, C.; Hedlund, K.; Hemerik, L. Urban and agricultural soils: Conflicts and trade-offs in the optimization of ecosystem services. Urban Ecosyst. 2014, 17, 239-253. [CrossRef]

71. Elmqvist, T.; Tuvendal, M.; Krishnaswamy, J.; Hylander, K. Managing Trade-Offs in Ecosystem Services. United National Environment Programme Division of Environmental Policy Implementation: Ecosystem Services Economics (ESE) Working Paper Series, Paper 4. 2013. Available online: http:unep.org/ ecosystemmanagement/Portals/7/Documents/WP04_Managing\%20tradeoffs_UNEP.pdf (accessed on 3 May 2016).

72. Santiago, L.E.; Ortiz, J.C.V.; Santiago-Bartolomei, R.; Meléndez-Ackerman, E.J.; Garcia-Montiel, D.C. Uneven access and underuse of ecological amenities in urban parks of the Río Piedras Watershed. Ecol. Soc. 2014, 19, 26. [CrossRef]

73. Commonwealth of Puerto Rico Regulations and Permits Administration. Building Code 1999; Commonwealth of Puerto Rico Regulations and Permits Administration: Santurce, Puerto Rico, 1999.

74. Commonwealth of Puerto Rico State Department. 2011 Puerto Rico Building Code: Amendments to the 2009 Building Code, Residential Code, Intl Mechanical Code, Intl Plumbing Code, Fire Code, Intl Fuel and Gas Code, Intl Energy Conservation Code, Intl Existing Building Code, Intl Private Sewage Disposal. 2011. Available online: http://www.jp.gobierno.pr/Portal_JP/Portals/0/Reglamentos/ 2011PUERTORICOBUILDINGCODEnuevo.pdf (accessed on 3 May 2016).

75. Sepúlveda, A. La isla que se achica: Evolución del urbanismo en Puerto Rico. Iberoam 1997, 3/4, $29-41$.

76. Rivera, A.S. Puerto Rico Urbano. Atlas Histórico de la Ciudad Puertorriqueña; Centro de Investigaciones CARIMAR and Departamento de Transportación y Obras Públicas: San Juan, Puerto Rico, 2004; volume 1.

77. Rodríguez-Meléndez, Y. Relevancia de la figura de servidumbre en equidad en el desarrollo y planificación del Puerto Rico actual: El caso de Puerto Nuevo. Univ. Puerto Rico Bus. Law J. 2012, 3, 101-110.

78. Verdejo-Ortiz, J. Valoración de los servicios de ecosistema: Aplicación del modelo hedónico en la cuenca del Río Piedras. PLERUS Rev. la Esc. Grad. Planif. (in press).

79. Office of Legislative Services. No. 260: An Act to Amend Sections 1 and 7 of Act No. 206 of August 28, 2003, to Include the Cupey Arboretum within the Ecological Corridor of San Juan. S.B. 2414, 14th Legislature of Puerto Rico, 7th Session; Office of Legislative Services: San Juan, Puerto Rico, 2004.

80. Hollander, J.B.; Pallagst, K.; Schwarz, T.; Popper, F.J. Planning shrinking cities. Prog. Plan. 2009, 72, $223-232$.

81. Martinez-Fernández, C.; Audirac, I.; Fol, S.; Cunningham-Sabot, E. Shrinking cities: Urban challenges of globalization. Int. J. Urban Reg. Res. 2012, 36, 213-225. [CrossRef] [PubMed]

82. Schilling, J.; Logan, J. Greening the rust belt: A green infrastructure model for right sizing America's shrinking cities. J. Am. Plan. Assoc. 2008, 74, 451-466. [CrossRef]

83. Ramus, C.A.; Killmer, A.B.C. Corporate greening through prosocial extrarole behaviours-a conceptual framework for employee motivation. Bus. Strateg. Environ. 2007, 16, 554-570. [CrossRef]

84. Allen, M. Strategic Communication for Sustainable Organizations: Theory and Practice; Springer: Berlin, Germany, 2015.

85. Molina-Rivera, W.L.; Gómez-Gómez, F. Estimated Water Use in Puerto Rico, 2005. U.S. Geological Survey Open-File Report 2008-1286. 2008. Available online: http://pubs.usgs.gov/of/2008/1286/OFR_2008_1286. pdf (accessed on 3 May 2016).

86. Environmental Protection Agency. Outdoor Water Use in the United States. Water Sense. 2016. Available online: http:/ / www3.epa.gov/watersense/pubs/outdoor.html (accessed on 3 May 2016).

87. Schueler, T. Urban pesticides: From the lawn to the stream. Watershed Prot. Tech. 1995, 2, 247-253.

88. Osmond, D.L.; Platt, J.L. Characterization of suburban nitrogen fertilizer and water use on residential turf in Cary, North Carolina. Horttechnology 2000, 10, 320-325.

89. Law, N.; Band, L.; Grove, M. Nitrogen input from residential lawn care practices in suburban watersheds in Baltimore County, MD. J. Environ. Plan. Manag. 2004, 47, 737-755. [CrossRef]

90. Swann, C. A Survey of Residential Nutrient Behaviors in the Chesapeake Bay. Widener-Burrows, Inc.; Chesapeake Research Consortium; Center for Watershed Protection: Ellicott City, MD, USA, 1999; p. 112.

91. Templeton, S.; Zilberman, D.; Yoo, S.J. Peer reviewed: An economic perspective on outdoor residential pesticide use. Environ. Sci. Technol. 1998, 32, 416A-423A. [CrossRef] 
92. Flint, M. Residential Pesticide Use in California: A Report of Surveys Taken in the Sacramento (Arcade Creek), Stockton (Five-Mile Slough) and San Francisco Bay Areas with Comparisons to the San Diego Creek Watershed of Orange County California; University of California Statewide IPM Program: Davis, CA, USA, 2003.

93. Home Advisor. How Much Does It Cost to Mow and Maintain a Lawn? 2014. Available online: http: / / www.homeadvisor.com/cost/lawn-and-garden/maintain-a-lawn/ (accessed on 3 May 2016).

94. Kard, B.; Shelton, K.; Luper, C. Pesticides in Residential Area-Protecting the Environment. Oklahoma Cooperative Extension Service, EPP-7461. 2013. Available online: http://pods.dasnr.okstate.edu/docushare/ dsweb/Get/Document-2341/EPP-7461web2013.pdf (accessed on 3 May 2016).

95. Guha, N.; Ward, M.H.; Gunier, R.; Colt, J.S.; Lea, C.S.; Buffler, P.A.; Metayer, C. Characterization of residential pesticide use and chemical formulations through self-report and household inventory: The Northern California Childhood Leukemia study. Environ. Health Perspect. 2013, 121, 276-282. [PubMed]

96. U.S. Census Bureau. Table DP-1: Profile of General Demographic Characteristics: 2000. 110th Congressional District Summary File (100-Percent); U.S. Census Bureau: Washington, DC, USA, 2000.

97. U.S. Census Bureau. Table DP-1: Profile of General Demographic Characteristics: 2000. Geographic Area: San Juan Municipio, Puerto Rico; U.S. Census Bureau: Washington, DC, USA, 2000.

98. R.C. Ltd. The Resonance Report; R.C. Ltd.: Vancouver, BC, Canada, 2014.

99. Act No 39 (B.S. 11). To Sections 5, 6, 8, 11, 12, 13, and 15 of Act No. 75 of July 5, 1995, as Amended, Known as the 'Special Act for the Rehabilitation of Río Piedras,' 2009. Available online: http:/ /www.oslpr.org/ download/en/2009/A-0039-2009.pdf (accessed on 3 May 2016).

100. Kruger, A.; Teja, R.; Wolfe, A. Puerto Rico-a Way Forward Report to the Commonwealth of Puerto Rico and The Government Development Bank for Puerto Rico. 2015. Available online: http:/ /www.bgfpr.com/ documents/puertoricoawayforward.pdf (accessed on 3 May 2016).

101. Marxuach, S. Despoblación. Perspectivas. 2012. Available online: http://www.estudiostecnicos.com/pdf/ perspectivas /2012/agosto2012.pdf (accessed on 3 May 2016).

102. Engl, R.; Zhao, M.Q.; Huang, J.-C. Impacts of Property Taxation on Residential Real Estate Development. J. Hous. Econ. 2013, 22, 45-53.

103. Municipal Property Tax Act of 1991, Act No. 83 of August 30, 1991, as amended. Available online: http://www2.pr.gov/presupuestos/Budget_2012_2013/Aprobado2013Ingles/suppdocs/baselegal_ ingles/208/83-1991.pdf (accessed on 30 January 2016).

104. Turner, V.K.; Ibes, D.C. The impact of homeowners associations on residential water demand management in Phoenix, Arizona. Urban Geogr. 2011, 32, 1167-1188. [CrossRef]

105. Beumer, C.; Martens, P. Biodiversity in my (back) yard: Towards a framework for citizen engagement in exploring biodiversity and ecosystem services in residential gardens. Sustain. Sci. 2015, 10, 87-100. [CrossRef]

(c) 2016 by the authors; licensee MDPI, Basel, Switzerland. This article is an open access article distributed under the terms and conditions of the Creative Commons Attribution (CC-BY) license (http://creativecommons.org/licenses/by/4.0/). 